Article

\title{
Women on the Border between Home and Homelessness: Analysing Worker-Client Relationship
}

\author{
Riitta Granfelt and Saija Turunen * \\ Y-Foundation, Finland; E-Mails: riitta.granfelt@ysaatio.fi (R.G.), saija.turunen@ysaatio.fi (S.T.) \\ * Corresponding author
}

Submitted: 30 March 2021 | Accepted: 4 June 2021 | Published: 26 August 2021

\begin{abstract}
Housing First, as implemented in Finland, offers two housing options for people who are homeless or at risk of homelessness. In this context, permanent housing refers to a scattered-site rental flat or a community-based housing unit in accordance with the Housing First principle. The focus of our study was on worker-client relationship and its diverse meanings at different stages of women's housing pathways. Our data consisted of narrative thematic interviews with nine women who lived in scattered housing and three workers of a housing unit. The narratives of the housing unit workers were related to a deep concern for the women who have the most limited choices and who do not always see the housing unit as home. The workers felt frustrated with the inconsistency of care pathways in substance abuse care, psychiatric hospital care as well as gerontological services. Women in scattered housing had received sufficient support at critical stages of their housing pathway from the public service system, which is an integral part of the Finnish Housing First model. In their cases, homelessness and problems with housing had been addressed as part of a holistic effort to improve the quality of their lives either through adult social work, child protection aftercare or psychosocial services. Getting sufficient support in a vulnerable situation in a trust-based worker-client relationship was a unifying theme of this dataset of women. Our study also challenges the development of services from the perspective of women whose housing pathways are characterised by numerous losses and exclusions, and for whom many services remain out of reach.
\end{abstract}

\section{Keywords}

female homelessness; home; Housing First; housing pathway; housing unit; worker-client relationship

Issue

This article is part of the issue "Home- and Community-Based Work at the Margins of Welfare: Balancing between Disciplinary, Participatory and Caring Approaches" edited by Kirsi Juhila (Tampere University, Finland), Cecilia Hansen Löfstrand (University of Gothenburg, Sweden) and Johanna Ranta (Tampere University, Finland).

(C) 2021 by the authors; licensee Cogitatio (Lisbon, Portugal). This article is licensed under a Creative Commons Attribution 4.0 International License (CC BY).

\section{Introduction}

In 2020, there were 1,065 homeless women in Finland, 25 percent of the total number of homeless people. Of these women, 189 were experiencing long-term homelessness and make up slightly less than 20 percent of the total number of long-term homeless individuals (ARA, 2021). This data is collected with an annual homelessness survey from Finnish municipalities. It contains people who have been registered as homeless in the services and therefore does not take into account hidden homelessness.
Since 2008, Finland has been implementing the Housing First principle, which has led to a gradual decrease in homelessness year after year. Housing First principle means that unhoused people are provided with independent rental flats and adequate support instead of temporary solutions such as hostels and shelters. The Finnish Housing First model was developed independently of the Pathways Housing First model in the United States but has similar features with it (Y-Foundation, 2017). It follows the core principles of Housing First as described in the Housing First Europe Guide (Pleace, 2016). In the Finnish context, these can be summarised 
into three themes: home of your own, rental contract based on law and adequate support if needed and wanted by the resident. In Finland, the implementation of housing and support may vary. Housing can mean an individual rental flat either in scattered housing located in social housing or in flats bought from the private market or in a supported housing unit where on-site personnel is often available. In both housing options, the rental lease is permanent. This research asks: What kinds of supportive relationships exist between clients and workers at the different stages of women's housing pathways? The question is approached from two complementary perspectives both produced in thematic narrative interviews: first as a workers' narrative from workers who do their work in a supported housing unit, and second as a women's narrative from women who live in scatteredsite flats. Both settings follow the Housing First principle. Our special interest is on the supportive worker-client relationship as part of homelessness intervention. As our aim was to study worker-client relationships at different stages of the housing pathways, we chose two significantly different research environments and interviewed both workers and clients.

The article proceeds in such a way that first (Section 2) we present the literature framing of our research, followed by (Section 3 ) the research settings, data and methods. Sections 4 and 5 are data-driven and present the research results we have generated based on our analysis. Section 6 contains the conclusions of the study.

\section{Previous Literature}

Several studies, starting from the pioneering study by Watson and Austerberry (1986), have shown the inadequacy, inexpedience, and attached associations of services for women (Bretherton \& Mayock, 2021; Mayock \& Bretherton, 2016; Mayock \& Sheridan, 2020, p. 27). Research has focused on diverse aspects on women's experiences with homelessness and housing services (e.g., Averitt, 2003, pp. 79-100; Cook et al., 2002, pp. 285-316; Haahtela, 2015; Skobba, 2016, pp. 41-58). The experiences of professionals working with homeless women have been explored from the perspectives of the strain of crisis intervention and coping with work-related stress (e.g., Baker et al., 2007, pp. 465-474; LemieuxCumberlege \& Taylor, 2019, pp. 367-378; Salem et al., 2018, pp. 665-687).

Homelessness pathway is a commonly used metaphor in homelessness studies in recent years (e.g., Clapham, 2002, pp. 57-68, 2003, pp. 119-127; Clapham et al., 2014, pp. 2016-2031; Fopp, 2009, pp. 271-291; Juhila \& Kröger, 2016; May, 2000, pp. 613-638). Numerous studies of social work (e.g., Järvinen, 2015, pp. 198-226; Karttunen, 2019, pp. 117-197; Ranta, 2020, pp. 86-88; Ruch, 2018, pp. 19-35) have shown the importance of a trust-based relationship for the success of interaction work. There has been a lot of research on home support (e.g., Juhila et al., 2020; Lydahl \& Hansen Löfstrand, 2020; Ranta et al., 2017) and besides research on women's homelessness has shown the importance of compassion and practical help for clients. Juhila et al. (2020) have conceptualised the unique content of home visit work into three dimensions: situationality, boundlessness, and empathy, framed by home as a context. On the other hand, Perälä and Jurvansuu (2016, pp. 532-537) have also shown the fact that the residents of a housing unit do not receive the substance abuse and mental health services they would be entitled to from the public sector. Research by Hansen Löfstrand (2015, pp. 17-38) shows the last resort shelter for the most marginalised homeless as a place of control and isolation from the rest of society. According to several studies women have perceived services as stigmatising, controlling and used only as a last resort when informal support has not been available (Bretherton \& Mayock, 2021).

As stated above, we participate in a research discussion on women's pathways to housing and service experiences by focusing on the worker-client relationship, from two complementary perspectives, and using two different interview data.

\section{Research Settings, Data and Methods}

The context of our research focusing on the workerclient relationship is the work of implementing the Housing First principle that takes place at different settings and stages of the women's pathway to housing and home. The data contains qualitative interviews conducted in two settings.

Our first setting is a supported housing unit that operates under the Housing First principle and which is targeted to long-term homeless women. The housing unit is owned by a non-governmental organisation who also provides the support and services for the women. In this setting we interviewed the workers. Our second research setting is rental flats in ordinary blocks of flats. These flats are owned by another non-governmental organisation which also implements the Housing First principle. In this research setting we met the women in their homes at a moment when they had just got their own flats and the preceding stages of their housing pathway were still fresh in their memory. The women looked back on the support they had received in worker-client relationships along their housing pathway and evaluated its significance in a place that they felt was their home.

The data which was collected through one group interview with three workers of a housing unit centres on their relationships with women who are suffering from psychosocial burden. All workers were female, they were trained as practical nurses and their work experience varied from a few months to four years. The housing unit, the setting in which the worker-client relationships are formed, is both a workplace and a community. Group interview as a method of data collection offers group participants an opportunity to diversify and 
refine each other's narratives. On the other hand, a group setting may create pressure to convey a unified narrative, which can limit or even prevent the expression of differing viewpoints (Esberg, 2020, pp. 49-52; Pietilä, 2017, pp. 112-121). The power dynamics within the group will inevitably influence what and how the participants speak. In our interview, there were disparities between the participants in terms of how much they spoke: The more experienced workers spoke more. Nevertheless, the participants were respectful towards each other and supported and complemented each other's comments. The interview conveyed a shared perception of the work, which is not a surprise since the participants work as a team in the unit.

The group interview consists of the workers' time-, setting- and encounter-specific views regarding their work and the women's situations. The significance of the setting and the community is highlighted in the ways how relationships with the women are described. Furthermore, relationships are described in relation to the women's life situations and the psychosocial stress associated with them. The group interview material has been analysed with data driven content analysis. The structuring of the themes was influenced by the interview frame we used, which we had compiled on the basis of our previous research literature and our knowledge of Finnish Housing First work. We first structured the overarching theme of worker-client relationship into four main themes: place, community, sensitive topics and coping at work. As a result of a more detailed analysis, we merged the theme of coping at work and the relevance of work into the other three, as their contents seemed to largely determine the meaning of the work and, on the other hand, the workload.

Our second dataset consists of nine one-on-one interviews, which were conducted in the homes of women who had exited homelessness or the risk of homelessness. The women were recruited for the interviews through housing counsellors. The selection criteria included that the women had moved to their scattered-site flats less than a year ago and that they received support either from the municipality or from a non-governmental organisation. The women's ages ranged from 18 to 66 years old. The participants included students, pensioners and working individuals. We interviewed mothers, grandmothers and childless women. Some had been homeless for years, whereas for others, homelessness had been an anomaly on their housing pathway. Some women's life courses had been marked by the risk of homelessness, yet they had not experienced homelessness. All of the women had low income, and some were struggling to pay off their debts.

We visited the women in their homes in order to acquire narratives based on their own experiences regarding the housing pathways that led them to a home of their own. The interviews were conducted with the help of loosely structured interview frame making sure that the women had as much freedom as possible to dis- cuss their experiences without a predetermined structure. We sought to understand the subjective meanings that the women assigned to the supportive relationships they had experienced or not along their housing pathways. Although the thematic questions guided and restricted the narratives, the women's experiences differed significantly in terms of their focus.

We analysed the women's interview material by selecting three interviews from the data corpus, two of which we built a story in which a young woman's homelessness path could have been prevented with sufficiently intensive and long-lasting support and supportive relationship in public child protection aftercare. From the two interviews, we selected extracts that describe the vulnerable life courses and, in particular, the meanings that a young woman gives to a worker she has experienced as her own. In another story, the theme is a traumatised life course in which psychosocial services with supportive relationships in public sector have played a major role in breaking the cycle of homelessness. Both stories are stories built with the aim of showing how the homeless woman's category breaks down into a wide variety of situations and lifestyles. The women's interview material is characterised by the importance of a timely, sufficiently long-term and trust-based workerclient relationships. In addition, the entire material is united by the significance of a home obtained on the principle of scattered-site and perceived as a home as part of the overall life situation.

Ethical reflections were given importance throughout the whole research process. Researchers submitted an application for access and research plan to both organisations of the research settings through the standard application process. After the application was approved, an information sheet was given to people we were recruiting for interviews. This sheet included basic information on the purpose of the research and emphasised voluntary participation and anonymity of participants (Kainulainen \& Honkatukia, 2021, p. 117). Before the interviews, all participants signed a consent form. The interviews were carried out by two researchers, both of whom were careful to emphasise the fact that participation in the research was voluntary and that what the women shared in the interviews would be treated as confidential and would in no way affect the services they received. We decided not to include signifiers to any of the quotations for two reasons. Firstly, the quotations of the workers represent the view of the whole team and our aim was not to highlight any differences. Secondly, with both datasets, we left signifiers out to guarantee the anonymity of our participants.

\section{Relationships with Homeless Women: Work at a Community-based Housing Unit}

Having a home can only improve quality of life if other core elements of psychiatric recovery are also present, such as hope for the future, meaningful 
activities, enjoying the company and support of others, and feeling included in society. However, permanent housing provides the conditions for normal, nonstigmatised housing. (Padgett, 2007, p. 1934)

This quotation from Padgett is the starting point for the analysis of our data: Support following the Housing First principle can mean working and creating relationships with women who feel homeless in their own home on a permanent tenancy.

Access to a flat does not always signify the end of the experience of homelessness, as one housing unit worker who participated in our study relates:

I haven't heard any one of our residents call their flat a home....They sometimes correct me if I talk about a home, they say "this is not my home."

Life without a home of your own means much more than just a lack of housing. A home has a deeper personal meaning than a flat, as it includes material, social and emotional dimensions. In order for a flat to become a home, the resident must attach it to her feelings. Attachment can be difficult and without support too overwhelming as a result of past experiences of homelessness or traumatic events related to breakdowns of homes (Granfelt, 1998, pp. 103-116; Ranta \& Juhila, 2019).

The place, in this case a housing unit, provides a backdrop and entangles to worker-client relationships. The interaction between the women who have experienced long-term homelessness and the housing unit workers is marked by psychosocial stress and the fact that for the women, housing services are a last resort option. An added strain may be caused by the feeling of homelessness, despite a permanent tenancy. For a person who is 'homeless at home' (Husso, 2003, pp. 220-229), a home no longer signifies a safe place of her own. Feeling homeless in one's own flat creates a tense to relationships in the unit: a housing service provider that follows the Housing First principle, yet a woman who feels homeless and whose opportunities for social participation are in many ways limited. Taking a step forward is difficult due to social exclusion, which many homeless women, especially those with serious mental health issues, have to face regardless of where and how they live (Padgett, 2007, p. 1934).

\subsection{The Place of Relationships}

The worker-client relationship forms the core of intervention, also in communities affected by various strains and conflicts (McMahon, 2018, pp. 147-164; Ranta, 2020 , p. 15). According to the workers, the traumatised life courses of individuals who have experienced long-term homelessness do not change course at once. These life courses have evolved over several years, even decades, maybe across generations, and reversing them requires not only a flat and support from professionals but also the experience of a meaningful life (e.g., Vanhala, 2005, pp. 184-185).

Pathways in and out of homelessness can be very complex, and linear development towards a 'final state' of a permanent home or permanent homelessness are rare (De Decker \& Segers, 2014, p. 611). The traumatic events suffered by women who have experienced longterm homelessness at different points of their life histories may have shattered the feeling of home so fundamentally that it has become difficult to grasp. They may never have had a home or may associate bad memories with various temporary lodgings, all of which for their part reinforce the feeling of homelessness. When relationship with the self is fractured and one's inner home is destroyed, it may be impossible to find a home anywhere. According to the workers, women's housing pathways included, in some cases, many evictions also from other supported housing units:

The social services have assigned this place for them. The other option is staying outside. When you take that choice away, I don't know whether it's really, whether it feels like home.

For homeless women, limited choice for housing is firmly linked to structural factors, such as the housing market and the social service system. From the women's perspective, this may essentially mean an absence of choice. The only available choice is not necessarily designed with their situations in mind and corresponds poorly to the needs of women in need of housing (Mayock \& Bretherton, 2016, pp. 278-280; Ranta et al., 2017, p. 173).

The workers of the housing unit expressed concern especially for the women whose lives were characterised by the question "Who would take me?":

These are individuals with psychogeriatric issues who return here after an assessment period and the years go by....Where does that person go when they get older, I do worry about that a lot.

A supported housing unit cannot address all possible social and health issues. A flat that is supposed to be a home for the women cannot become a repository for psychosocial issues (Perälä \& Jurvansuu, 2016, pp. 532-533).

\subsection{Community Relationships}

In the housing unit, relationships are strained by untreated substance abuse and mental health issues as well as the cumulative traumatic experiences that underlie and intertwine them. Communal living with strangers who are stigmatized with the same categories of problems may feel like objectionable, forced interaction. An unwell client may isolate herself inside a hard shell: 
Respondent: They don't want to deal with us. And if they are intoxicated, their behaviour is often very aggressive. Towards us counsellors, and also towards the other residents.

Interviewer: If there's a resident who is paranoid, how does that manifest here?

Respondent: Well, it will manifest as distrust towards us. And everything that happens, it's our fault. And the fact that we are able to control both their finances as well as their personal matters. We are here in order to make their life difficult....We become the embodiment of all their misfortunes. We are at fault for what happened to them.

Understanding the culture of homelessness and what socially excluded and stigmatised women have experienced and continue to experience helps workers protect themselves from taking aggressions and insults personally. The education of workers being in close relation with homeless women must be developed by providing a deeper and broader understanding of women's homelessness as a phenomenon, which will enhance their cultural competence. Workers must possess diverse skills in order to support, communicate and create trustful relationships with women who receive services. These skills also include recognising that the women may have complicated relationships with services. This is why they frequently rely on the help of frontline workers, who can respond to their crises with a more sensitive approach (Lemieux-Cumberlege \& Taylor, 2019, p. 368):

A rough day is one when your phone is ringing from the moment you come to work in the morning. Either it's the residents calling you or our partners, cleaners, laundry services. And since our doors are closed, we always have to be opening the doors. Then the alarm system goes off....The constant demands. And meanwhile your phone keeps ringing. And you can't even hear the person at the other end because of the noise. Then you try to find a quieter place.

The workers in the housing unit work in small teams of two in the daytime and alone at weekends. At times they come under high levels of time pressure to complete multiple tasks simultaneously. This may cause stress, especially combined with lack of time or an excessive workload. Eventually, the danger is that this will potentially contribute to both emotional exhaustion and affect one's sense of personal accomplishment. On the other hand, the sense of personal accomplishment related to one's work may act as a protective measure against burnout (Baker et al., 2007, p. 471). Looking beneath the surface and trying to understand a person's circumstances can help professionals cope with challenging worker-client relationships. Similarly, seeing one's work as meaningful can have a strong positive effect on work engagement
(Mette et al., 2020, p. 10; Salem et al., 2018, pp. 670-672; Ward, 2018, pp. 55-74). Satisfaction and the experience of meaningful relationships were reinforced by small interactional episodes which were characterised by few, but honest words:

Our residents are also able to say sorry. And it comes straight from the heart.

It can be just a small thing, and when they thank you. It doesn't have to be anything major but they are grateful for many things.

One resident called and said: "It's nice that you returned from your holidays."

According to the workers the housing unit community can be experienced differently by different women. For some, it may represent an objectionable last resort characterised by negative relationships and disillusionment. For others, it may represent a home associated with positive aspects such as safety, shared space and shared identities among women, and social relationships. The women within the community may already know each other from earlier stages in their housing pathways, and they may have a sense of community that is grounded in shared experiences (Hetling et al., 2020, p. 412; Junnilainen, 2019, pp. 76-119; Nousiainen, 2016, pp. 163-191). The workers discussed the significance of community interaction with elderly women who have lived in the community for a long time:

For example, if someone hasn't seen a particular resident in a few days, they will often call us and ask if everything is okay with them because they haven't seen her. We will go and check and if everything is okay, we will tell her it's fine. They take care of each other.

Through their presence, the workers can show their appreciation for the sense of community among the women and acknowledge their right to be treated respectfully as individuals. Such activity can be referred to as presence intervention. The relationship based on presence signifies spending time together, either in conversation or in silence. The worker is present and available, even until the very end (Granfelt, 2013, pp. 231-237; Haahtela, 2015, pp. 54-57; Karttunen, 2019, pp. 135-146):

We have a common space on the fifth floor where we have coffee together. Often at the weekends if I'm alone here, I'll just sit there for hours and talk with the women about anything and everything.

We have also accompanied them on their final journey, so we have gone to funerals and since we are close, we can't help but cry when we send them off 
on their final journey. So, it's not, it's not easy for us either. It's impossible to do this job without becoming close to them.

\subsection{Sensitive Topics: Unspoken Narratives}

And I guess it's also because some of them have spent their whole lives on the streets, so they have kind of become hardened, and they need to remain like that no matter what....They are hurting, but they don't know why they are hurting.

Even though the workers make themselves available and are present in various situations, the shared reality and the underlying emotional connection is difficult to achieve, especially if the women have had many difficult experiences that they are unable to confront:

They talk very, very little.... think they are sensitive topics and they might be ashamed. Or it might make them feel so upset that they don't want that. So, they just numb themselves with drugs or alcohol, it's kind of an endless cycle. It's somewhere inside them, but it never gets out.

The workers state that the women are unable to discuss or share their trauma or cumulative history of trauma. They have had to survive on the street and in unsafe lodgings. They have learned to survive with the help of armour, which protects them from insults and rejection but simultaneously prevents them from accepting compassion and care (Thörn, 2004, pp. 153-185). The women may have adopted a cross-generational culture of reticence since childhood. They are building neither a victim narrative nor a narrative of agency; instead, they are building a sad, unspoken narrative. Substance abuse may provide a barrier for unbearably difficult emotions (Granfelt, 1998, pp. 142-145).

The women's experiences with the service system may also have contributed to the formation of a hard shell. Rejection may signify an even stronger attachment to violence, drugs and illness, which in turn may result in guilt and shame, staying silent and shielding oneself from the eyes of others. Such rejections may have cumulated along one's life history. Women's negative experiences and relationships with services may also result from a perceived lack of control or say in their everyday lives and feelings of surveillance and infantilisation, as attempts to 'order' their lives may have had significant negative ramifications (Mayock \& Sheridan, 2020, p. 27; Vanhala, 2005, p. 270; Virokannas, 2017, pp. 274-283).

The restrictions set by the housing unit also contribute to the idea of a community of dysfunctional women. Research on women's homelessness has broadly discussed issues related to motherhood (Granfelt, 1998, pp. 117-132; van den Dries et al., 2016, pp. 179-208). Homelessness and the loss of home may be accompanied by unspoken and broken motherhood. If a woman's children have been taken into care, her motherhood is not always recognised and her possibilities to fulfil her motherhood are not explored. Living separately from one's own children and missing them can be too heavy a topic to share with the workers and other women:

Based on what I have understood, I think she hasn't seen them and she misses them terribly. And it may come up when she is reminiscing on things that she used to do with her children. Then she often says she misses them. And you kind of have to be discreet....I never got the chance to ask her if she ever meets them... it's such a sensitive subject, so I can't really ask her.

Above one of the workers discuss how greatly she thinks one of the women misses her children. Bringing up such a heavy topic in worker-client relationship does not seem possible despite the fact that the woman had reminisced on moments she had spent with her children. Ethically challenging situations rarely indicate a clear approach; instead, the worker must make intuitive decisions (e.g. Juhila, 2018, pp. 253-257). It is possible that the woman in question wished that the worker would have taken a more forthcoming approach. It is equally possible that she appreciated the present, yet distant relationship. Since the workers are involved in the women's daily lives, it is important that they are able to respect the women's privacy. Respecting the women was embodied in one principle that was shared among the team, which was to make sure that whatever is promised to the women will also happen:

Even something trivial, if it has been agreed upon, we will make sure it gets done.

\section{Pathway towards a Home of your Own}

Our second dataset consists of interviews with women who have received a flat of their own. The women had moved into their flats relatively recently, within the previous year. In the interviews, we discussed the stages on their pathway to home and the meaning of home. Each of the nine women had received psychosocial and/or financial support along their housing pathway. The women's housing pathways differed significantly. Some had lived in a cycle of crime, drugs and homelessness for years and after years in supported housing, had finally acquired a home of their own. Others had retired from a low-income career, which resulted in spiralling debts and foreclosures, and finally eviction.

The following two narratives describe the situations of women who have, with the help of psychosocial support in their worker-client relationships, been able to avoid becoming homeless or to break the cycle of marginalisation and start forging a new identity. The first narrative is based on interviews with two young women, and the second one on one interview. 


\subsection{The First Home of One's Own}

"I'm mentally better now," she says.

Difficult teenage years took this woman who feels now mentally better away from home to a children's home. She discussed her difficult teenage years and yearning for peace and quiet amidst the bustle of the child protection facility. Her biggest source of safety had been a large dog, who remained with her through everything. Now her situation was different: She was about to graduate into a profession that she loved, she was dating and living in her first own home. She was also close to securing a job. A new home, a flat with a permanent tenancy on the top floor of a quiet building, just as she had hoped:

There is a door code and you can't get in just like that and it's a bit higher so it's not the lowest level. It just feels safe in that sense even though there is only one exit. Because of some things in my childhood, it is really important for me.

Her narrative includes description of a close, supportive and helpful worker-client relationship. She had looked for her own flat together with a social worker from child protection aftercare services. Together, they had considered different options and filled in rental applications. The social worker had accompanied her to an interview with a non-profit organisation, which offered her a flat. The social worker had encouraged her to express her wishes regarding the flat.

As soon as she saw the flat she knew: "Yes, this is it." The flat was clean and beautifully renovated. The building housed mostly elderly people, and her childhood home was a short distance away. Although the neighbourhood has a reputation as a problem suburb, it did not bother or scare her.

The social worker helped her get started with independent living. Anne is "probably the best social worker I've had, sound and understanding; the kind of person it's easy to be with, easy to talk to. Anne gets back to me immediately after she sees my message." She took care of the paperwork and discussed all kinds of things related to a young person's life. There were things she didn't want to discuss with her parents. It was good to have another adult in her life.

She did not need support for living. She was able to cook and keep a clean home. She had previously taken care of her younger siblings, who enjoyed spending time at her place, in her new home. Now she had a place of her own where she could invite her friends. She liked it at home so much that "sometimes I don't really want to leave it. This is my own safe haven." She had started to trust her own capabilities and to see the possibilities that were open to her. Having "a place that cannot just be taken away and people around me who help me so that I'm not alone" gave her a sense of security.
Having a worker you connect with is highly significant to a young person living in a vulnerable situation. Child protection aftercare services promote independence, and secured housing is a prerequisite for independence. The client-worker relationship involves the same basic elements as client-worker relationships in the housing unit: trust, sharing meaningful things and support with practical matters. An interactional space where the client feels at ease is the foundation for mutual sharing and boosts confidence: People care about me and want to help me.

The narrative is characterised by two significant factors. The first one is the availability of support at a critical stage on one's housing pathway, when the young person is about to transition to her first own flat. When she was a teenager, she had to leave her childhood home and move to a child protection facility, which was a difficult experience. The young person has lived independently from an early age and, at the same time, is about to transition to working life. Her life course is guided by traumatic events, which is why it is very important that she receives professional support at the critical stage of transition. Another significant factor is renting a flat that feels safe from a non-profit organisation that is committed to helping residents with financial and other issues that may jeopardise housing. Listening to the young person's wishes and ensuring her freedom of choice, however limited, regarding the flat contributes significantly to creating a feeling of home.

For young women, homelessness can signify a rapidly advancing process of marginalisation (e.g., Viisanen, 2019) and mark the beginning of a sad narrative. At the time of the interviews, the narrative taking shape was positive and hopeful about the future.

\subsection{From Rehabilitation to Studies}

The woman in our second narrative told she had been under psychiatric care several times, both in inpatient and outpatient care, and defined herself as a person in mental health rehabilitation:

For a long time I kind of held it together, but then I started getting into debt. I also had a gambling problem and my debts grew and grew and because of that my drug use and mental health got worse and worse.

The insufferable situation led to a suicide attempt, after which she found her strength:

Immediately after I was discharged from the hospital, I contacted the substance abuse centre and got a quick appointment and after two weeks I went to a rehabilitation facility. I was first taken in for a month and then for another month. And that was definitely a turning point for me. 
She was given a place in a rehabilitation housing community for women, but she felt like an outsider among the women who were much older than her. She lived with her sister sometimes, and occasionally she would stay with friends.

She got her drug use under control and started psychotherapy. Because she was homeless, a commitment to regular psychotherapy sessions proved too challenging, but she found help through a low-threshold organisation that also arranged for a flat. She went back to psychotherapy and started studies in a degree programme. Recently she had begun to identify herself decreasingly as a person undergoing rehabilitation from mental health and substance abuse issues and increasingly as a student:

And it feels really good because for so many years it was like the drugs and the mental health issues completely defined me.

She was herself amazed at how she had been able to remain sober for months without a flat. She had cried when she did the laundry for the first time in her own home:

I can't stress enough how meaningful housing is. I don't know where my path would have taken me if I didn't get a home of my own. It could have taken me in a very different direction because it was stressful staying in other people's homes.

This woman's situation is very different compared to the women whom the workers of the housing unit were most concerned about. She had timely access to psychiatric care, institutional rehabilitation and outpatient services. At the final stage of her care path, she found a form of psychotherapy that suited her. All in all, she had several trustful, supportive and helpful worker-client relationships. She was no longer bouncing between acquaintances, and her identity was shifting from that of a person in rehabilitation from mental health and substance abuse issues to that of a student.

\section{Conclusion}

The narratives of the housing unit workers related to a deep concern for the women whose mental and physical health was deteriorating. The workers had to assume responsibility for the safety of clients with psychotic symptoms and to work in an environment where some women were unable to take care of themselves and their flats. Workers felt frustrated by the inconsistence of care pathways in substance abuse care, psychiatric hospital care as well as gerontological services. Despite the emotional stress the workers felt their work as meaningful and discussed their affection for the women. Although the support given in the housing unit includes boundlessness and situationality (Juhila et al., 2020), this should not result in women being excluded from the special services. With an empathetic and flexible approach to clients' situations, more or less trust-based relationships were formed in the housing unit, which gave meaning to the work and thus supported the resilience of the workers.

The housing unit does not provide women a normal and non-stigmatising flat (Padgett, 2007) but neither it is a guarded last resort for people in the extreme margin of society (Hansen Löfstrand, 2015). For some women, the housing unit provides communal support, sharing a common history of experience about the way of life that is vulnerable in many ways. The workers of the housing unit have limited possibilities to influence the marginalisation that extends to various areas of women's life. However, this does not diminish the significance of worker-client relationships in the unit in the lives of women for whom many services still remain out of reach.

Our second research setting was a rental flat in scattered housing. Trustful, supportive and helpful workerclient relationships at different stages of the housing pathway and in different services enabled for their part access to a flat that became a home, including a sense of home. In both narratives, the woman had received what she needed from social and healthcare services. Getting sufficient support and help in a vulnerable situation in a trust-based worker-client relationship was a unifying theme of narratives of the women. Homelessness and problems with housing have been addressed as part of a holistic effort to improve quality of life together with the women either through adult social work, through child protection aftercare or through psychosocial services. Besides, the women had access to their own resources, such as studies and employment, and close personal relationships that supported coping. There was hardly any need for housing support as such. The public service system, which is an integral part of the Finnish Housing First model, had been able to provide sufficient support in the critical stages of the housing pathway for women whose situations, despite their vulnerability, were not chaotic pathways burdened by accumulated deprivation. Our research encourages the further development of trauma-oriented working methods and low threshold women-only housing options, from the perspective of women living in a spiral of marginalisation who trust no one.

\section{Acknowledgments}

The authors wish to thank all participants involved in the research, who gave their time freely and provided invaluable insights to the study, and the anonymous reviewers for their helpful comments.

\section{Conflict of Interests}

The authors declare no conflict of interests. 


\section{References}

ARA. (2021). Homelessness in Finland 2021. The Housing Finance and Development Centre.

Averitt, S. S. (2003). "Homelessness is not a choice!" The plight of homeless women with preschool children living in temporary shelters. Journal of Family Nursing, 9(1), 79-100. http://doi.org/10.1177/ 1074840702239492

Baker, L. M., O'Brien, K. M., \& Salahuddin, N. M. (2007). Are shelter workers burned out? An examination of stress, social support, and coping. Journal of Family Violence, 22, 465-474.

Bretherton, J., \& Mayock, P. (2021). Women's homelessness: European evidence review. Research report. FEANTSA. https://www.feantsa.org/en/report/ 2021/04/01/womens-homelessness-europeanevidence-review

Clapham, D. (2002). Housing pathways: A postmodern analytical framework. Housing, Theory and Society, 19(2), 57-68. http://doi.org/10.1080/ 140360902760385565

Clapham, D. (2003). Pathways approaches to homelessness research. Journal of Community \& Applied Social Psychology, 13, 119-127. http://doi.org/ 10.1002/casp. 717

Clapham, D., Mackie, P., Orford, S., Thomas, I., \& Buckley, K. (2014). The housing pathways of young people in the UK. Environment and Planning, 46(8), 2016-2031.

Cook, C. C., Crull, S. R., Fletcher, C. N., Thessalenuere, H.-B., \& Peterson, J. (2002). Meeting family housing needs: Experiences of rural women in the midst of welfare reform. Journal of Family and Economic Issues, 23(3), 285-316.

De Decker, P., \& Segers, K. (2014). Chaotic, fluid and unstable: An exploration of the complex housing trajectories of homeless people in Flanders, Belgium. Journal of Housing and the Built Environment, 29, 595-614. http://doi.org/10.1007/s10901-0139367-0

Esberg, R. (2020). Iranista Suomeen muuttaneiden naisten sosiaaliset suhteet ja niiden merkitys yhteiskuntaan kiinnittymisessä [The significance of social relations on the integration of women who have moved from Iran to Finland; Doctoral dissertation, University of Turku]. UTUPUB. https://www.utupub.fi/handle/ $10024 / 150451$

Fopp, R. (2009). Metaphors in homelessness discourse and research: Exploring "pathways," "careers" and "safety nets." Housing, Theory and Society, 26(4), 271-291. http://doi.org/10.1080/14036090802476 564

Granfelt, R. (1998). Kertomuksia naisten kodittomuudesta [Stories of female homelessness]. SKS.

Granfelt, R. (2013). Asumissosiaalinen työ läsnäolotyönä -Kokemuksia naisten yhteisöstä [Housing-related social work as presence-work-Experiences from a women's community]. In M. Laitinen \& A. Niskala (Eds.), Asiakkaat toimijoina sosiaalityössä [Clients as actors in social work] (pp. 219-243). Vastapaino.

Haahtela, R. (2015). Asiakkuuksien rakentuminen asunnottomille suunnatussa naistyössä [Constructing meanings for clienthoods at women-specific housing related social work]. Acta Universitatis Tamperensis.

Hansen Löfstrand, C. (2015). The policy of homeless shelter: Private security patrolling the border of eligibility. European Journal of Homelessness, 9(2), 17-38. https://www.feantsaresearch.org/download/ lofstrand_ejh2-2015article135967112661723 00554.pdf

Hetling, A., Dunford, A., \& Botein, H. (2020). Community in the permanent supportive housing model: Applications to survivors of intimate partner violence. Housing, Theory and Society, 7(4), 400-416.

Husso, M. (2003). Parisuhdeväkivalta. Lyötyjen aika ja tila [Gendered violence within intimate relationships]. Vastapaino.

Järvinen, M.-K. (2015). Asiakas-työntekijäsuhde rikosseuraamusalalla. Dialoginen arviointi tiedontuotannon tapana [Client-worker relationship in the criminal sanctions field. Dialogical evaluation as a method of knowledge creation; Doctoral dissertation, University of Tampere]. Trepo. https://trepo.tuni.fi/ bitstream/handle/10024/96536/978-951-44-96837.pdf?sequence $=1 \&$ isAllowed $=\mathrm{y}$

Juhila, K. (2018). Aika, paikka \& sosiaalityö [Time, place and social work]. Vastapaino.

Juhila, K., \& Kröger, T. (Eds.). (2016). Siirtymät ja valinnat asumispoluilla [Transitions and choices in housing pathways]. SoPhi.

Juhila, K., Löfstrand, C., \& Raitakari, S. (2020). Devoted work without limits? Activities and premises of home visit work at the margins of community care. International Journal of Care and Caring, 1(16). https:// doi.org/10.1332/239788220X16032965398106

Junnilainen, L. (2019). Lähiökylä. Tutkimus yhteisöllisyydestä ja eriarvoisuudesta [A place where you matter. Communality and inequality in public housing neighbourhoods]. Vastapaino.

Kainulainen, H., \& Honkatukia, P. (2021). Tutkijan eettinen vastuu sensitiivisessä tutkimushaastattelussa [The ethical responsibility of the researcher in a sensitive research interview]. In K. Nieminen \& N. Lähteenmäki (Eds.), Empiirinen oikeustutkimus [Empirical legal research] (pp. 115-130). Gaudeamus.

Karttunen, T. (2019). Naiserityistä päihdehoitoa. Etnografinen tutkimus päihdelaitoksen naisyhteisöstä [Components of female-specific drug treatment. Ethnographical study at a women's community; Doctoral dissertation, University of Jyväskylä]. Jyväskylä University Digital Repository. https:// jyx.jyu.fi/bitstream/handle/123456789/65481/978951-39-7839-6_vaitos28092019.pdf?sequence=1\& isAllowed=y

Lemieux-Cumberlege, A., \& Taylor, E. P. (2019). An 
exploratory study on the factors affecting the mental health and well-being of frontline workers in homeless services. Health \& Social Care in the Community, 27(4), 367-378. http://doi.org/10.1111/hsc.12738

Lydahl, D., \& Hansen Löfstrand, C. (2020). Doing good: Autonomy in the margins of welfare. Sociology of Health and Illness, 42(4), 892-906. https://doi.org/ 10.1111/1467-9566.13069

May, J. (2000). Housing histories and homeless careers: A biographical approach. Housing Studies, 15(4), 613-638. http://doi.org/10.1080/0267303005008 1131

Mayock, P., \& Bretherton, J. (2016). Conclusions. In P. Mayock \& J. Bretherton (Eds.), Women's homelessness in Europe (pp. 265-286). Palgrave Macmillan.

Mayock, P., \& Sheridan, S. (2020). A feminist poststructuralist perspective. European Journal of Homelessness, 14(2), 13-43.

McMahon, L. (2018). Long-term complex relationships. In G. Ruch, D. Turney, \& A. Ward (Eds.), Relationshipbased social work (2nd ed., pp. 147-164). Jessica Kingsley Publishers.

Mette, J., Robelski, S., Wirth, T., Nienhaus, A., Harth, V., \& Mache, S. (2020). "Engaged, burned out, or both?" A structural equation model testing risk and protective factors for social workers in refugee and homeless aid. International Journal of Environmental Research and Public Health, 17. http://doi.org/ 10.3390/ijerph17020583

Nousiainen, K. (2016). Oma ovi yhteisössä: Pitkäaikaisasunnottomien asumispolut ja asumiseen liittyvät valinnat [Private place at a housing unit for long-term homeless people: Housing pathways and choices]. In K. Juhila \& T. Kröger (Eds.), Siirtymät ja valinnat asumispoluilla [Transitions and choices in housing pathways] (pp. 163-191). SopHi.

Padgett, D. K. (2007). There's no place like (a) home: Ontological security among persons with serious mental illness in the United States. Social Science \& Medicine, 64, 1925-1936.

Perälä, R., \& Jurvansuu, S. (2016). Politiikasta käytännöksi. Asunto ensin-politiikan arkea asumisyksiköiden työntekijöiden kertoman [From policy to practice. The everyday application of housing first policies as told by housing services employees]. Yhteiskuntapolitiikka, 5, 528-537.

Pietilä, I. (2017). Ryhmäkeskustelu [Group interview]. In M. Hyvärinen, P. Nikander, \& J. Ruusuvuori (Eds.), Tutkimushaastattelun käsikirja [Handbook of qualitative reseach] (pp. 111-128). Vastapaino.

Pleace, N. (2016). Housing first guide Europe. FEANTSA.

Ranta, J. (2020). Suhteellinen toimijuus huumeita käyttävien matalan kynnyksen palveluissa. Tutkimus institutionaalisesta vuorovaikutuksesta [Relational agency in low-threshold services for people using drugs: A study of institutional interaction; Doctoral dissertation, Tampere University]. Trepo. https:// trepo.tuni.fi/handle/10024/122717

Ranta, J., \& Juhila, K. (2019). Constructing a sense of home in floating support for people using drugs. Qualitative Social Work, 19(4), 685-700. http://doi. org/10.1177/1473325019847262

Ranta, J., Raitakari, S., \& Juhila, K. (2017). Vastuuneuvottelut huumeidenkäyttäjien asunnottomuuden toiminnallisissa loukuissa [Negotiating responsibilities in the double binds of drug users' homelessness]. Yhteiskuntapolitiikka, 82(2), 165-175.

Ruch, G. (2018). The contemporary context of relationship-based practice. In G. Ruch, D. Turney, \& A. Ward (Eds.), Relationship-based social work (2nd ed., pp. 19-35). Jessica Kingsley Publishers.

Salem, B. E., Kwon, J., \& Ames, M. (2018). On the frontlines: Perspectives of providers working with homeless women. Western Journal of Nursing Research, 40(5), 665-687.

Skobba, K. (2016). Exploring the housing pathways of low-income women: A biographical approach. Housing, Theory and Society, 33(1), 41-58. http://doi.org/ 10.1080/14036096.2015.1059356

Thörn, C. (2004). Kvinnans plats(er)-bilder av hemlöshet [Women's places-Pictures of homelessness]. Égalité.

van den Dries, L., Mayock, P., Gerull, S., van Loenen, T., van Hulst, B., \& Wolf, J. (2016). Mothers who experience homelessness. In P. Mayock \& J. Bretherton (Eds.), Women's homelessness in Europe (pp. 179-208). Palgrave Macmillan.

Vanhala, A. (2005). Paikka ja asiakkuus. Etnografia naisten asuntolasta [Place and clienthood. Ethnographical study at a women's shelter; Doctoral dissertation, Tampere University]. Trepo. https://trepo. tuni.fi/bitstream/handle/10024/96654/978-951-449713-1.pdf?sequence $=1$

Viisanen, M. (2019). "Se on ihan kaikki kaikessa, että on koti": Nuorten naisten kokemuksia kodittomuudesta ja sen merkityksistä ["Having a home of your own is all that matters": Experiences of homelessness and its diverse meanings as told by young women; Master's thesis, University of Lapland]. Lauda. https://lauda.ulapland.fi/bitstream/handle/10024/ 63849/Pro\%20gradu\%20Viisanen\%202019.pdf? sequence $=1 \&$ isAllowed $=y$

Virokannas, E. (2017). Eriarvoisuuden kokemuksia ja hallinnan suhteita hyvinvointipalvelujärjestelmässä. Huumeita käyttävien naisten "standpoint" [Experiences of inequality and ruling relations in the welfare service system from the standpoint of female substance abusers]. Yhteiskuntapolitiikka, 82(3), 274-283.

Ward, A. (2018). The use of self in relationship-based practice. In G. Ruch, D. Turney, \& A. Ward (Eds.), Relationship-based social work (2nd ed., pp. 55-74). Jessica Kingsley Publishers.

Watson, S., \& Austerberry, H. (1986). Housing and homelessness: A feminist perspective. Routledge \& Kegan Paul.

Y-Foundation. (2017). Home of your own. Housing First and ending homelessness in Finland. Ottawa. 


\section{About the Authors}

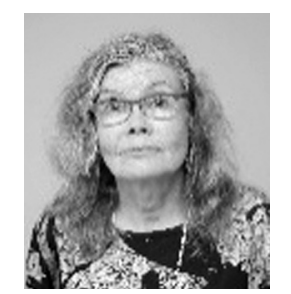

Riitta Granfelt (PhD) is a Docent at the University of Helsinki and currently works as a Researcher in the Y-Foundation. She has a long career in Finnish homelessness research and her main research areas are female homelessness and psycho-social services for socially excluded groups, like female prisoners and released prisoners. Besides, she has been working as a Senior Lecturer of social work at the University of Helsinki and Turku.

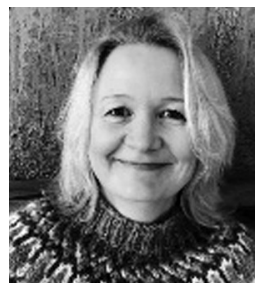

Saija Turunen (PhD) is Research Manager at Y-Foundation, Finland, where she has worked since 2017. Saija studied at the University of Bangor, North Wales, and worked in the field of social research in the UK for several years. Currently Saija co-leads the research work cluster of the Housing First Europe Hub and her research interests include impact assessment, women's homelessness as well as subjective well-being. 